\title{
Analisis Pengaruh Keselamatan dan Kesehatan Kerja (K3) dan Lingkungan Kerja terhadap Kinerja Karyawan di PT.Samudera Perdana
}

\author{
Manda Dwipayani Bhastary ${ }^{1)}$, Kusri Suwardi ${ }^{2)}$ \\ 1) Program Studi Manajemen, Sekolah Tinggi Ilmu Ekonomi Tricom \\ e-mail: manda_bhastary@yahoo.com \\ ${ }^{2)}$ Program Studi Manajemen, Sekolah Tinggi Ilmu Ekonomi Tricom \\ e-mail: kusri.suwardi@samudera.com
}

\begin{abstract}
Abstrak
PT. Samudera Perdana, sebagai perusahaan yang bergerak dalam kegiatan usaha transportasi barang di darat (land transportation) tentu harus memiliki program K3 yang efektif. Program K3 harus diutamakan, sebab PT. Samudera Perdana memiliki 6 kegiatan utama yang berada banyak diluar lapangan, seperti pengangkutan kargo peti kemas \& pemilik barang langsung, reposisi peti kemas kosong, distribusi kargo, pengangkutan kargo proyek \& angkutan pelabuhan, mesin dan peralatan yang digunakan kemungkinan besar dapat menyebabkan kecelakaan bagi pekerja apabila tidak digunakan secara tepat yang dapat mempengaruhi kinerja karyawannya. Metode analisis data yang digunakan adalah regresi berganda. Hasil penelitian pada hipotesis menunjukkan bahwa variabel Keselamatan dan Kesehatan kerja (K3) dan Lingkungan kerja secara serempak maupun parsial menunjukkan pengaruh signifikan terhadap Kepuasan Kerja karyawan dimana sebesar 68,4\% variasi variabel Kinerja dapat dijelaskan oleh variasi variabel $K 3$ dan Lingkungan Kerja, sedangkan sisanya 31,6\% divariasi oleh faktor-faktor lain yang tidak diteliti dalam penelitian ini.
\end{abstract}

Kata kunci: Keselamatan dan Kesehatan Kerja, Lingkungan kerja, Kinerja

\section{PENDAHULUAN}

PT. Samudera Perdana, sebagai perusahaan yang bergerak dalam kegiatan usaha transportasi barang di darat (land transportation) tentu harus memiliki program K3 yang efektif. Program K3 harus diutamakan, sebab PT. Samudera Perdana memiliki 6 kegiatan utama yang berada banyak diluar lapangan, seperti pengangkutan kargo peti kemas \& pemilik barang langsung, reposisi peti kemas kosong, distribusi kargo, pengangkutan kargo proyek \& angkutan pelabuhan, mesin dan peralatan yang digunakan kemungkinan besar dapat menyebabkan kecelakaan bagi pekerja apabila tidak digunakan secara tepat yang dapat mempengaruhi kinerja karyawannya.

Kecelakaan kerja yang terjadi di PT. Samudera Perdana kebanyakan terjadi dikarenakan oleh pekerja itu sendiri, misalnya pada waktu melaksanakan pekerjaan tidak disiplin dalam hal penggunaan APD (Alat Pelindung Diri), tidak mematuhi Standar Operasional Prosedur (SOP), dan penggunaan mesin dan peralatan yang salah.

Sebenarnya perusahaan dalam hal ini telah berupaya untuk mengurangi tingkat kecelakaan kerja, melaui peningkatan kedisiplinan dan pemberian sangsi tegas bahkan telah memberikan berbagai 
program seperti program pelatihan dan sebagainya, sehingga kecelakaan kerja memang telah berkurang dari tahun ke tahunnya. Hal ini dapat dilihat dari data berikut:

\section{Gambar 1. Data Kecelakaan Kerja di PT. Samudera Perdana}

Tahun 2016-2017

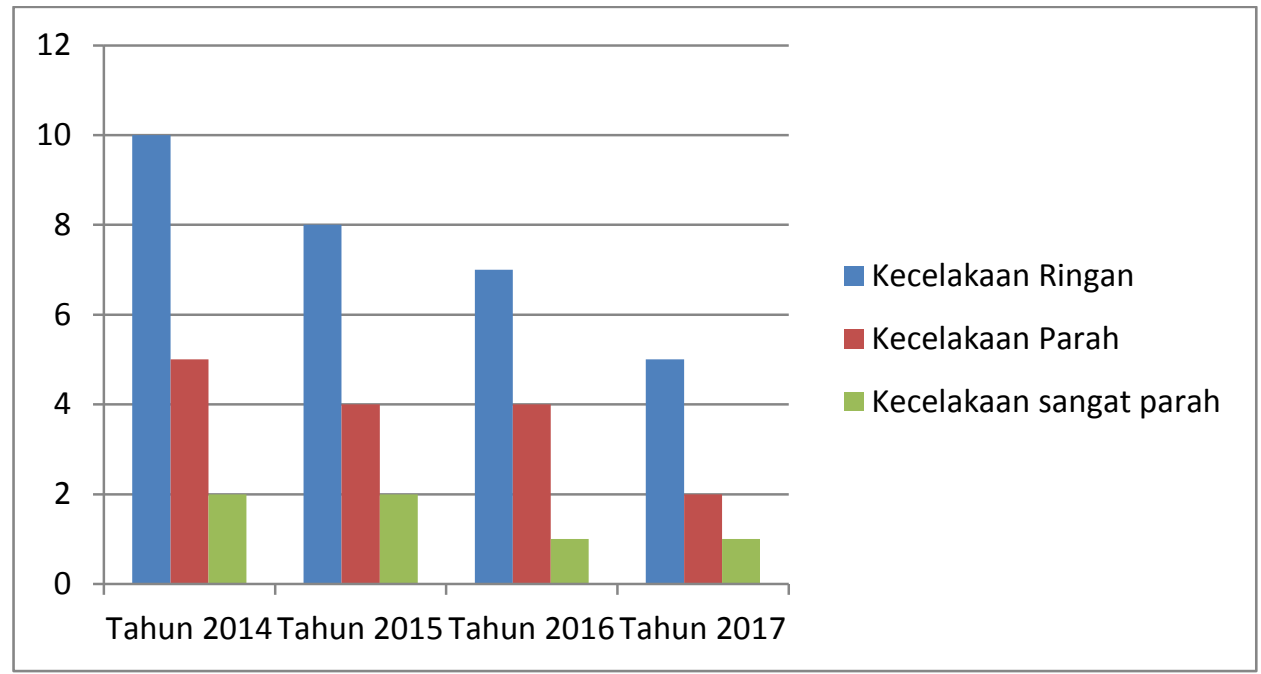

Sumber: PT. Samudera Perdana (bagian personalia)

Berdasarkan gambar 1 menunjukkan bahwa program Kesehatan dan Keselamatan Kerja (K3) yang ada di PT. Samudera Perdana sebenarnya sudah berjalan baik, terlihat adanya penurunan angka kecelakaan kerja dari tahun 2012 sampai dengan tahun 2015. Pada tahun 2012 total terjadi 10 kasus kecelakaan ringan, seperti kecelakaan karena tidak menggunakan APD pada mesin forklift, 5 kasus kecelakaan parah pada saat proses bongkar muat barang terluka akibat peralatan produksi yang ada dan 2 kasus kecelakaan parah akibat kecelakaan lalu lintas di jalan raya.

Pada tahun-tahun seterusnya kasus kecelakaan kerja mulai berkurang, pada tahun 2013 kecelakaan parah hanya 4 kasus dan 2 kasus kecelakaan sangat parah, sedangkan pada tahun 2014 hingga 2015 hanya terjadi kecelakaan 5 kasus kecelakaan kerja ringan, 2 kasus kecelkaan parah dan 1 kasus kecelakaan sangat parah.

Walaupun perusahaan sudah menerapkan system OHS (Occupational Health \& Safety) yaitu kesehatan dan keselamatan kerja karyawan. Sehingga dari tahun ke tahun kecelakaan kerja tidak banyak terjadi di lingkungan kerja namun system tersebut harus terus dilakukan evaluasi agar tercapai tingkat zero accident (tidak ada kecelakaan kerja sama sekali).

Perusahaan harus terus berupaya untuk meningkatkan kinerja seluruh karyawannya agar mampu bersaing dengan perusahaan lain karena dapat menghasilkan suatu barang atau jasa dengan cara yang lebih efisien. Kinerja merupakan tingkat keberhasilan seseorang secara keseluruhan selama periode tertentu didalam melaksanakan tugas dibandingkan dengan berbagai kemungkinan seperti standart hasil kerja, target atau sasaran atau kriteria yang telah ditentukan terlebih dahulu dan telah di sepakati bersama. Hal ini akan dapat tercapai apabila perusahaan selalu memperhatikan faktor Keselamatan dan Kesehatan Kerja (K3) serta lingkungan kerja karena hal ini akan dapat meningkatan kinerja karyawan. 
Lingkungan kerja merupakan faktor yang paling banyak mempengaruhi perilaku karyawan terutama dalam lingkungan pekerjaan yang secara tidakn langsung maupun langsung mempengaruhi kinerja karyawan, Tohardi (2002), mengatakan bahwa jika lingkungan kerja yang tidak baik tentunya akan memberikan dampak negatif terhadap para pekerja, yaitu menurunkan semangat kerja, gairah kerja, dan kepuasan kerja yang akhirnya menurunkan kinerja karyawan. Perusahaan harus dapat memperhatikan kondisi yang ada dalam perusahaan baik di dalam maupun di luar ruangan tempat kerja, sehingga karyawan dapat bekerja dengan lancar dan merasa aman.

Lingkungan kerja dalam suatu perusahaan sangat penting untuk diperhatikan manajemen. Meskipun lingkungan kerja tidak melaksanakan proses produksi dalam suatu perusahaan tetapi lingkungan kerja mempunyai pengaruh langsung terhadap para karyawan yang melaksanakan proses produksi tersebut.

Lingkungan kerja yang baik bagi karyawannya dapat meningkatkan kinerja sebaliknya lingkungan kerja yang tidak baik dapat menurunkan kinerja karyawan. Lingkungan kerja yang ada PT Samudera Perdana harus mendapatkan perhatian agar pekerjaan dapat terlaksana secara optimal. Dengan diterapkannya OHS (Occupational Health \& Safety), diharapkan dari tahun ke tahun kecelakaan kerja tidak banyak terjadi di lingkungan kerja.

Tujuan penelitian ini adalah:

1. Untuk menguji dan menganalisis pengaruh Keselamatan dan Kesehatan Kerja (K3) terhadap Kinerja karyawan pada PT. Samudera Perdana?

2. Untuk menguji dan menganalisis pengaruh Lingkungan Kerja terhadap Kinerja karyawan pada PT. Samudera Perdana

3. Untuk menguji dan menganalisis pengaruh Keselamatan dan Kesehatan Kerja (K3) dan Lingkungan kerja secara serempak terhadap Kinerja karyawan pada PT. Samudera Perdana.

\section{TINJAUAN PUSTAKA}

\section{Teori Tentang Keselamatan dan Kesehatan Kerja (K3)}

Keselamatan dan Kesehatan Kerja (K3) merupakan perhatian dan perlindungan yang diberikan perusahaan kepada seluruh karyawannya. Menurut Mathis dan Jackson (2006), Keselamatan dan Kesehatan Kerja (K3) adalah kegiatan yang menjamin terciptanya kondisi kerja yang aman, terhindar dari gangguan fisik dan mental melalui pembinaan dan pelatihan, pengarahan dan kontrol terhadap pelaksanaan tugas dari para karyawan dan pemberian bantuan sesuai dengan aturan yang berlaku, baik dari lembaga pemerintah maupun perusahaan dimana mereka bekerja.

\section{Keselamatan Kerja}

Menurut Husni (2005), keselamatan kerja bertalian dengan kecelakaan kerja yaitu kecelakaan yang terjadi di tempat kerja atau dikenal dengan istilah kecelakaan industri. Kecelakaan industri ini 
secara umum dapat diartikan: suatu kejadian yang tidak diduga semula dan tidak dikehendaki yang mengacaukan proses yang telah diatur dari suatu aktivitas. Ada 4 (empat) faktor penyebabnya yaitu:
a. Faktor manusianya.
b. Faktor material/bahan/peralatan.
c. Faktor bahaya/sumber bahaya.
d. Faktor yang dihadapi (pemeliharaan/perawatan mesin-mesin).

\section{Kesehatan Kerja}

Kesehatan kerja menunjukkan pada kondisi yang bebas dari gangguan fisik, mental, emosi atau rasa sakit yang disebabkan oleh lingkungan kerja. Resiko kesehatan merupakan faktor-faktor dalam lingkungan kerja yang bekerja melebihi periode waktu yang ditentukan, Lingkungan yang dapat membuat stress emosi atau gangguan fisik (Mangkunegara, 2000).

Kesehatan kerja dimaksudkan untuk memberi perlindungan bagi pekerja terhadap pemerasan (eksploitasi) tenaga kerja oleh majikan misalnya untuk mendapatkan tenaga yang murah. Kesehatan kerja merupakan penjagaan agar buruh melakukan pekerjaan yang layak bagi kemanusiaan dan tidak hanya ditunjuk terhadap pihak majikan yang hendak melakukan pemerasan tenaga pekerja, tetapi juga ditujukan terhadap pekerja itu sendiri, dimana dan bilamana pekerja misalnya hendak memboroskan tenaganya dengan tidak mengindahkan kekuatan jasmani dan rohaninya. Kesehatan kerja merupakan suatu hal yang penting dan perlu diperhatikan oleh pihak pengusaha. Karena dengan adanya program kesehatan yang baik akan menguntungkan para karyawan secara material, karena karyawan akan lebih jarang absen, bekerja dengan lingkungan yang lebih menyenangkan, sehingga secara keseluruhan karyawan akan mampu bekerja lebih lama (Mangkunegara, 2000).

\section{Teori Tentang Lingkungan Kerja}

Lingkungan kerja (the work environment) adalah sumber daya dan situasi yang dibutuhkan oleh seseorang untuk melakukan. Tempat atau lingkungan kerja dalam perusahaan akan mempengaruhi terhadap pekerjaan karyawan. Lingkungan kerja yang buruk akan menyebabkan karyawan merasa terganggu dalam pekerjaannya dan akan menyebabkan turunnya kinerja pegawai.

Suatu kondisi lingkungan kerja dikatakan baik atau sesuai apabila manusia dapat melaksanakan kegiatan secara optimal, sehat, aman dan nyaman. Kesesuaian lingkungan kerja dapat dilihat akibatnya dalam jangka waktu yang lama. Lebih jauh lagi lingkungan-lingkungan kerja yang kurang baik dapat menuntut tenaga kerja dan waktu yang lebih banyak dan tidak mendukung diperolehnya rancangan sistem kerja yang efisien. Nitisemito (2005) mendefinisikan lingkungan kerja adalah segala sesuatu yang ada disekitar para pekerja yang dapat mempengaruhi dirinya dalam menjalankan tugas-tugas yang diembankan. 


\section{Teori Tentang Kinerja}

Menurut Rivai (2004) bahwa kinerja adalah perilaku nyata yang ditampilkan setiap orang sebagai prestasi kerja yang dihasilkan oleh karyawan sesuai dengan perannya dalam perusahaan. Sedangkan Riani (2011) menyatakan bahwa kinerja karyawan adalah hasil seseorang secara keseluruhan selama periode tertentu di dalam melaksanakan tugas seperti standar hasil kerja, target atau sasaran atau kriteria yang telah ditentukan terlebih dahulu dan telah disepakati bersama.

\section{Teori Pengaruh Keselamatan dan Kesehatan Kerja (K3) Terhadap Kinerja}

Menurut Mathis dan Jackson (2006), Keselamatan dan Kesehatan Kerja (K3) adalah kegiatan yang menjamin terciptanya kondisi kerja yang aman, terhindar dari gangguan fisik dan mental melalui pembinaan dan pelatihan, pengarahan dan kontrol terhadap pelaksanaan tugas dari para karyawan dan pemberian bantuan sesuai dengan aturan yang berlaku, baik dari lembaga pemerintah maupun perusahaan dimana mereka bekerja. Manajemen keselamatan dan kesehatan kerja pada dasarnya mencari dan mengungkapkan keselamatan dan secara optimal yang memungkinkan terjadinya kecelakaan dan meneliti apakah pengendalian kecelakaan sudah dilakukan perusahaan dengan cermat sehingga dapat menurunkan angka kecelakaan kerja tersebut.

\section{Teori Pengaruh Lingkungan Kerja Terhadap Kinerja}

Slemania (2008) menyatakan bahwa tinggi rendahnya kinerja karyawan dipengaruhi oleh faktor kenyaman kerja yang mana hal itu juga dipengaruhi oleh faktor lingkungan kerja. Ketidaknyaman saat bekerja merupakan kondisi yang sangat tidak baik bagi tenaga kerja dalam beraktivitas, karena pekerja akan melakukan aktivitasnya yang kurang optimal dan akan menyebabkan lingkungan kerja yang tidak bersemangat dan membosankan, sebaliknya apabila pekerja akan melakukan aktivitas dengan optimal, dikarenakan kondisi lingkungan pekerjaan yang sangat baik dan mendukung.

\section{Penelitian Terdahulu}

Fahmawati (2004) meneliti dengan judul "Pengaruh Kesehatan dan Keselamatan Kerja (K3) Serta Lingkungan Kerja Terhadap Kinerja Karyawan pada PT. Cahaya Surya Tunas Tapioka Wonogiri". Hasil uji F sebesar 24,120 menunjukkan bahwa kesehatan dan keselamatan kerja serta lingkungan kerja mempunyai pengaruh yang signifikan terhadap kinerja karyawan. hasil uji t sebesar 4,260 menunjukkan bahwa Kesehatan dan Keselamatan Kerja berpegaruh signifikan terhadap kinerja karyawan sebesar dan hasil uji t sebesar 4,98 menunjukkan bahwa lingkungan kerja berpengaruh signifikan terhadap kinerja karyawan dan koefisien determinan sebesar 0,556 menunjukkan bahwa variabel bebas (kesehatan dan keselamatan kerja serta lingkungan kerja) dapat menjelaskan 56,6\% terhadap variabel terikat (kinerja karyawan).

Khaerurahman (2007) meneliti dengan judul "Pengaruh Kesehatan dan Keselamatan Kerja (K3) Terhadap Kinerja Karyawan Pada PT. Sinar Sosro Cabang Gresik”. Hasil uji F menunjukkan 
bahwa kesehatan dan keselamatan kerja mempunyai pengaruh yang signifikan terhadap kinerja karyawan sebesar 19,642 dan hasil uji t menunjukkan bahwa keselamatan kerja berpengaruh signifikan terhadap kinerja karyawan sebesar 2,882 terhadap kinerja karyawan, dan kesehatan kerja mempunyai pengaruh signifikan terhadap kinerja sebesar 3,136 koefisien determinasi ( $\mathrm{R}$ square) sebesar 0,40 menunjukkan bahwa variabel bebas (Kesehatan dan Keselamatan Kerja) dapat menjelaskan $40 \%$ terhadap variabel terikat (Kinerja Karyawan).

Dewi (2006) meneliti dengan judul "Pengaruh Keselamatan dan Kesehatan Kerja (K3) Terhadap Kinerja Karyawan pada PT Ecogreen Oleochemical Medan Plant". Hasil penelitian menunjukkan adanya pengaruh positif dan signifikan antara Keselamatan dan Kesehatan Kerja (K3) Terhadap Kinerja Karyawan sebesar 52,2\% secara serentak maupun secara parsial.

\section{Kerangka Pemikiran}

Hubungan antara variabel bebas dengan variabel terikat dapat dilihat dalam kerangka konseptual seperti pada Gambar 1 berikut:

\section{Gambar 2. Kerangka Konseptual}

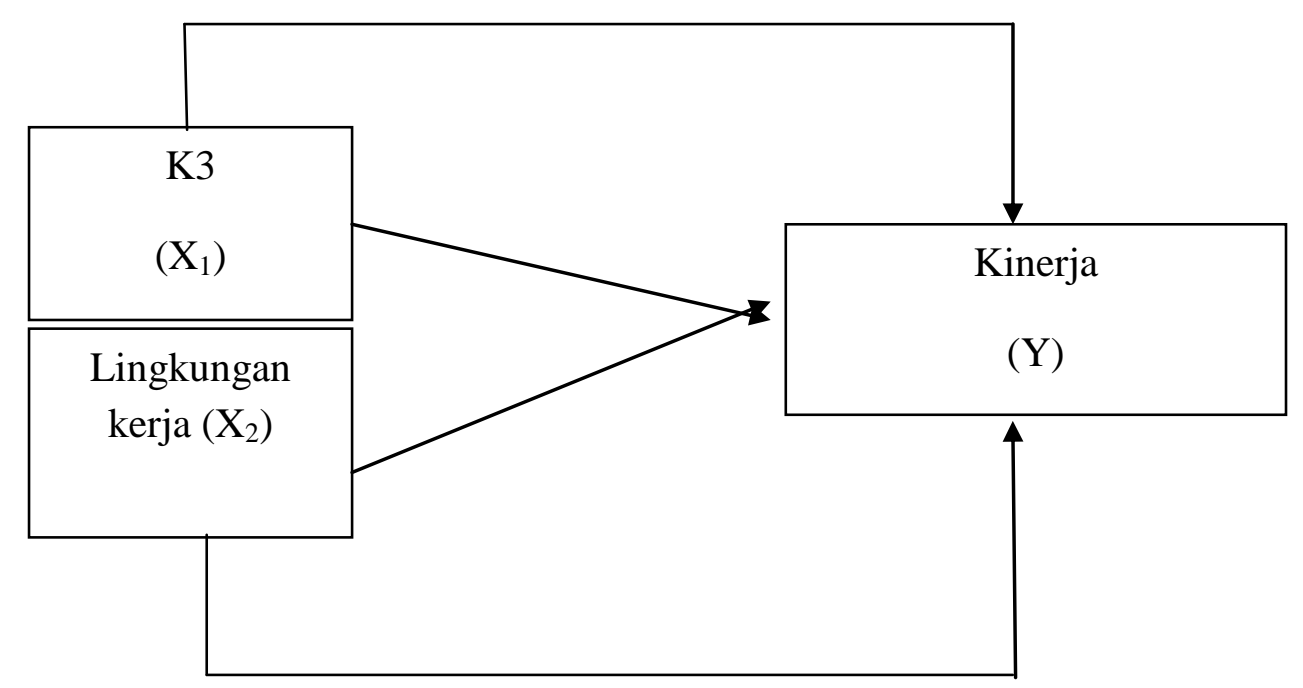

\section{Hipotesis Penelitian}

Berdasarkan kerangka konseptual diatas, maka hipotesis yang dibuat dalam penelitian ini adalah:

1. Keselamatan dan Kesehatan Kerja (K3) berpengaruh terhadap kinerja karyawan pada PT. Samudera Perdana.

2. Lingkungan kerja berpengaruh terhadap kinerja karyawan pada PT. Samudera Perdana.

3. Keselamatan dan Kesehatan Kerja (K3) dan Lingkungan kerja secara serempak berpengaruh terhadap kinerja karyawan pada PT. Samudera Perdana. 


\section{METODE PENELITIAN}

\section{Objek dan Waktu Penelitian}

Penelitian ini dilakukan di PT. Samudera Perdana JL. Raya Pelabuhan Gabion Belawan. Samudera Logistics Centre Medan. Waktu penelitian direncanakan dari bulan Oktober 2017 sampai dengan Maret 2018.

\section{Populasi dan Sampel}

Menurut Sugiyono (2009), Populasi merupakan sekumpulan objek yang ditentukan melalui kriteria dan dapat dikategorikan ke dalam objek tersebut berupa manusia, dokumen-dokumen, dan alat-alat organisasi lainnya. Populasi dalam penelitian ini adalah karyawan di PT. Samudera Perdana dengan jumlah karyawan sebanyak 164 orang.

Menurut Sugiyono (2009), Sampel adalah bagian dari jumlah dan karakteristik yang dimiliki oleh populasi tersebut. Untuk menentukan jumlah sampel, peneliti menggunakan rumus Slovin. Rumus Slovin adalah sebagai berikut:

$$
n=\frac{N}{1+N e^{2}}
$$

Di mana:

$$
\mathrm{n}=\text { ukuran sampel }
$$

$\mathrm{N}=$ ukuran populasi

$\mathrm{e}=$ persen kelonggaran ketidaktelitian karena kesalahan pengambilan sampel yang masih dapat ditolerir (5\%).

Dengan populasi sebanyak 164 orang dan tingkat kesalahan (e) sebesar 5\%, maka sampel (n) penelitian ini adalah:

$$
\begin{aligned}
& n=\frac{164}{1+(164)(0,005)^{2}} \\
& n=\quad 63 \text { orang }
\end{aligned}
$$

Jadi sampel penelitian ini adalah sebanyak 63 orang.

\section{Teknik Pengumpulan Data}

Menurut Sugiyono (2010:137), teknik pengumpulan data yang digunakan adalah:

1. Wawancara (Interview), dengan melakukan tanya jawab secara langsung dengan karyawan PT. Samudera Perdana bagian personalia untuk memperoleh informasi mengenai Keselamatan dan Kesehatan Kerja ( K3 ), Lingkungan Kerja, dan kinerja karyawan.

2. Daftar pertanyaan (Questionare), dengan membuat daftar pertanyaan dalam bentuk kuesioner yang ditujukan kepada karyawan PT. Samudera Perdana. 


\section{HASIL DAN PEMBAHASAN}

Analisis Statistik Deskriptif

Tabel 1. Hasil Uji Statistik Deskriptif

Descriptive Statistics

\begin{tabular}{lllllll}
\hline & N & Minimum & Maximum & Sum & Mean & $\begin{array}{l}\text { Std. } \\
\text { Deviation }\end{array}$ \\
\hline Kinerja & 63 & 43 & 68 & 4420 & 42,32 & 3,771 \\
K3 & 63 & 30 & 50 & 3139 & 41,92 & 4,552 \\
Lingkungan Kerja & 63 & 34 & 50 & 3328 & 44,54 & 3,600 \\
Valid N (listwise) & 63 & & & & &
\end{tabular}

Sumber: Hasil Penelitian 2018 (data diolah )

Statistik Deskriptif berkenaan dengan bagaimana data dapat digambarkan (dideskripsikan) atau disimpulkan baik secara numerik (misalnya menghitung rata-rata dan deviasi standar) atau secara grafis ( dalam bentuk tabel atau grafik) untuk mendapatkan gambaran sekilas mengenai data tersebut sehingga lebih mudah dibaca dan bermakna. Dari tabel diatas dapat dilihat bahwa nilai rata-rata dari Keselamatan dan Kesehatan Kerja (X1) adalah 41.92 dengan standar deviasi 4,552 dan Lingkungan Kerja (X2) dengan rata-rata 44.54 dengan standar deviasi 3.600. Begitu juga dengan Kepuasa Kerja (Y) dengan nilai rata-rata 42.18 dengan standar deviasi 3.771.

\section{Pengujian Asumsi Klasik}

Sebelum melakukan pengujian hipotesis dari penelitian ini, terlebih dahulu dilakukan pengujian asumsi klasik untuk memastikan bahwa alat uji regresi berganda dapat digunakan atau tidak. Apabila uji asumsi klasik telah terpenuhi, maka alat uji statistik regresi berganda dapat dipergunakan.

\section{Uji Normalitas}

Uji normalitas terbagi menjadi dua pengujian yaitu:

1. Analisis Grafik

Pada diagram pencar hasil olah data SPSS dengan dasar pengambilan keputusan yakni jika data menyebar disekitar garis diagonal dan mengikuti arah garis diagonal, maka model regresi memenuhi asumsi normalitas. Uji dengan menggunakan grafik terbagi menjadi dua yaitu:

a. Grafik Histogram

Hasil pengujian dapat dilihat pada grafik dibawah ini:

Gambar 3. Hasil Uji Normalitas dengan Metode Histogram

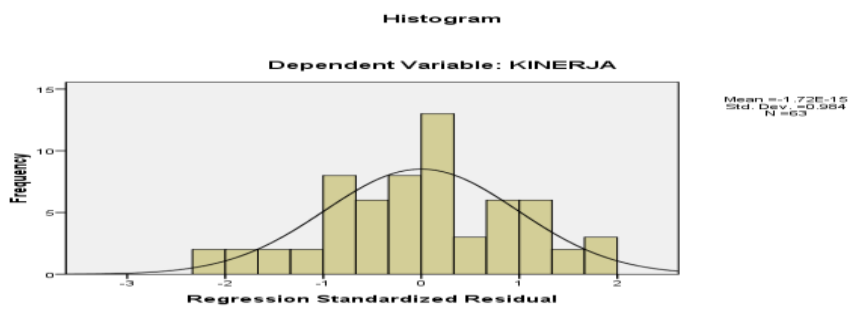

Sumber: Hasil Penelitian 2018 (data diolah ) 
Dari Gambar 3 dapat dilihat bahwa data menyebar hingga membentuk sebuah lonceng dan distribusi data tersebut melenceng ke kanan maupun ke kiri, maka pengujian data tersebut dinyatakan berdistribusi normal.

b. Grafik P-P Plot

Hasil pengujian dapat dilihat pada grafik berikut ini:

\section{Gambar 4. Hasil Uji Normalitas dengan Metode P-P Plot}

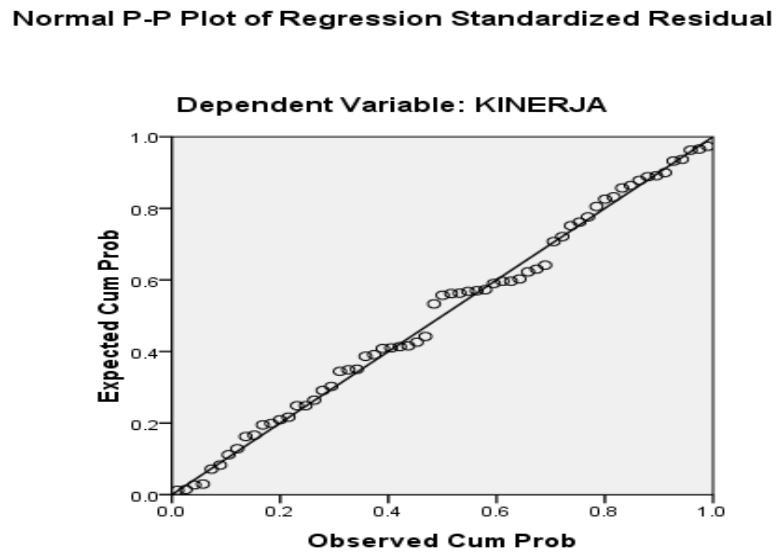

Sumber: Hasil Penelitian 2018 (data diolah )

Dari Gambar 4 dapat dilihat bahwa data menyebar disekitar garis diagonal, dan tidak ada data yang letaknya jauh dari garis diagonal tersebut, maka data ini dinyatakan berdistribusi normal.

2. Uji menggunakan statistik yaitu dengan metode Kolmogorov-Smirnov. Hasil pengujiannya dapat dilihat pada Tabel 2 berikut ini :

Tabel 2. Hasil Uji dengan Metode Kolmogorov-Smirnov.

\section{One-Sample Kolmogorov-Smirnov Test}

\begin{tabular}{lll}
\hline & & Unstandardized Residual \\
\hline N & & 75 \\
\hline Mormal Parameters & Mean &, 0000000 \\
\cline { 2 - 3 } & Std. Deviation & 2,53940760 \\
& Absolute &, 091 \\
\cline { 2 - 3 } & Positive &, 091 \\
\cline { 2 - 3 } & Negative &,- 069 \\
\hline Test Statistic & &, 091 \\
\hline Asymp. Sig. (2-tailed) & &, $200^{\text {c,d }}$ \\
\hline a. Test distribution is Normal. & & \\
\hline
\end{tabular}

Calculated from data 
Berdasarkan hasil output pada Tabel 2 diperoleh nilai Asym. Sig 2-tailed sebesar 0,200. Karena signifikansi lebih besar dari 5\% $(0,05)$ sehingga dapat disimpulkan bahwa data yang diuji berdistribusi normal.

\section{Uji Multikolinearitas}

Uji Multikolieniritas bertujuan untuk mengetahui korelasi antar variabel independent dan ini dapat dilihat dari Variance Inflation Factor (VIF) dengan catatan apabila VIF >10 maka diduga mempunyai persoalan multikolinearitas dan apabila VIF $<10$ maka tidak terjadi multikolinearitas. Hasil pengujiannya dapat dilihat pada Tabel 3 berikut ini:

\section{Tabel 3. Hasil Uji Multikolieniritas}

\section{Coefficients $^{\mathrm{a}}$}

\begin{tabular}{llllll}
\hline & \multicolumn{2}{l}{$\begin{array}{l}\text { Unstandardized } \\
\text { Coefficients }\end{array}$} & $\begin{array}{l}\text { Standardized } \\
\text { Coefficients }\end{array}$ & Collinearity Statistics & \\
\cline { 2 - 6 } Model & $\mathrm{B}$ & Std. Error & Beta & Tolerance & VIF \\
\hline 1 (Constant) & 7.957 & 3.378 & & & \\
K3 & .539 & .076 & .650 & .601 & 1.664 \\
LINGKUNGAN_KERJA & .265 & .097 & .253 & .601 & 1.664 \\
\hline
\end{tabular}

a. Dependent Variable: KINERJA

Sumber : Hasil Penelitian 2018 (data diolah )

Pada Tabel 3 diatas hasil variabel K3 dan Lingkungan Kerja memiliki nilai VIF $<10$ dan nilai tolerance mendekatri 1 . Hal ini menunjukkan tidak terjadi gejala multikolinearitas.

\section{Uji Heteroskedastisitas}

Uji Heteroskedastisitas bertujuan untuk menguji apakah dalam model regresi terjadi kesamaan variance dari residual satu pengamatan ke pengamatan yang lain. Variance dari residual satu pengamatan ke pengamatan yang lain tetap, maka disebut Homoskedatisitas dan jika berbeda disebut heteroskedatisitas, hasil pengujian dapat dilihat pada gambar dibawah ini:

\section{Gambar 5. Hasil Uji Heteroskedastisitas}

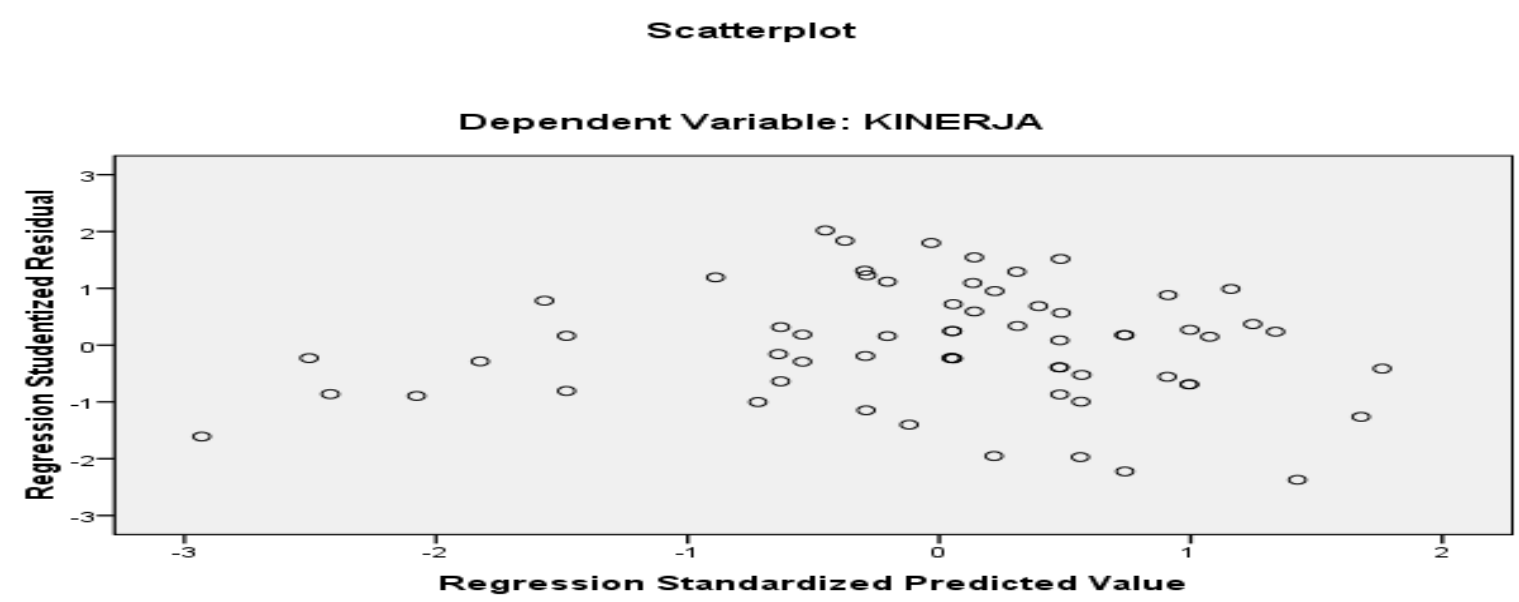

Sumber : Hasil Penelitian 2018 (data diolah ) 
Berdasarkan Gambar Scatterplot di atas diketahui bahwa titik-titik yang dihasilkan menyebar secara acak dan tidak membentuk suatu pola atau trend garis tertentu. Gambar di atas juga menunjukkan bahwa sebaran data ada di menyebar secara acak di atas dan di bawah titik nol. Hasil pengujian ini menunjukkan bahwa model persamaan regresi hipotesis pertama ini bebas dari masalah heteroskedastisitas.

\section{Pembahasan}

Analisis data penelitian yang digunakan dalam penelitian ini adalah model analisis regresi berganda. Model analisis ini digunakan untuk mengetahui pengaruh variabel independen terhadap variabel dependen baik secara bersama-sama maupun secara parsial. Adapun hasil output perhitungan dari proses SPSS adalah sebagai berikut :

Tabel 4 .Hasil Analisis Statistik

\begin{tabular}{lrcc}
\hline \multicolumn{1}{c}{ Variabel } & $\mathrm{B}$ & $\mathrm{t}$ & Sig.t \\
\hline Konstanta & 7.957 & 2.355 & .022 \\
K3 & .539 & 7.055 & .000 \\
Lingkungan Kerja & .265 & 2.475 & .008 \\
\hline Adjusted R.Square & .684 & & \\
F & 67.974 & & \\
Sig. F & 0.000 & &
\end{tabular}

Sumber : Hasil Penelitian 2018 (data diolah )

Dari Tabel 4, maka dapat dirumuskan persamaan regresi berganda sebagai berikut:

$\mathbf{Y}=\mathbf{a}+b_{1} X_{1}+b_{2} X_{2}+\mathrm{e}$

$\mathrm{Y}=7.957+0.539 x_{1}+0.265 x_{2}+0.05$

\section{Pengujian Hipotesis Secara Parsial (Uji t)}

Berdasarkan Tabel 4, diperoleh sebagai berikut:

1. Uji Parsial Variabel K3

Dari tabel tersebut dapat dilihat bahwa nilai $t_{\text {hitung }}>t_{\text {tabel }}(7,055>2,000)$ dengan signifikan (Sigt) sebesar 0.000 lebih kecil dari $\alpha=5 \%(0,05)$. Maka dalam hasil penelitian menerima $H_{1}$ dan menolak $H_{0}$, artinya $\mathrm{K} 3$ berpengaruh positif dan signifirkan terhadap Kinerja karyawan di PT.Samudra Perdana

2. Uji Parsial Variabel Lingkungan Kerja

Dari tabel tersebut dapat dilihat bahwa nilai $t_{\text {hitung }}>t_{\text {tabel }}(2,742>2,000)$ atau signifikan (Sig-t) sebesar lebih kecil dari $\alpha=5 \%(0,05)$. Maka dalam hasil penelitian menolak $H_{0}$ dan menerima $H_{1}$, artinya Lingkungan Kerja berpengaruh signifikan terhadap Kinerja karyawan di PT. Samudera Perdana. 


\section{Pengujian Hipotesis Secara Simultan (Uji F)}

Berdasarkan Tabel 4 diperoleh bahwa nilai $F_{\text {hitung }}>F_{\text {tabel }}(67.974>3.11)$ dan Sig. $\left(0.000^{b}\right)$ lebih kecil dari $\alpha=5 \%$ (0.05). Dapat disimpulkan bahwa hasil penelitian menolak $H_{0}$ dan menerima $H_{1}$. Dengan demikian Keselamatan dan kesehtan kerja $(\mathrm{K} 3)\left(X_{1}\right)$ dan Pelatihan $\left(X_{2}\right)$ secara serempak berpengaruh signifikan terhadap Kinerja (Y) karyawan pada PT. Samudera Perdana

\section{Koefisien Determinasi Hipotesis $\left(\boldsymbol{R}^{2}\right)$}

Dari hasil output program SPSS, maka diperoleh nilai Adjusted $R$ Square sebesar 0.684 yang artinya sebesar 68,4\% variasi variabel Kepuasan Kerja dapat dijelaskan oleh variasi variabel K3 dan Lingkungan kerja, sedangkan sisanya 31,6\% divariasi oleh faktor-faktor lain yang tidak diteliti dalam penelitian ini

\section{Pengaruh Keselamatan dan Kesehatan Kerja (K3) terhadap Kinerja Karyawan}

Pada hasil penelitian diperoleh, variabel K3 berpengaruh signifikan terhadap Kinerja karyawan di PT. Samudera Perdana. Hasil penelitian ini sejalan dengan hipotesis penelitian yang menyatakan bahwa K3 berpengaruh terhadap Kinerja karyawan di PT.Samudera Perdana. Hasil penelitian ini sesuai dengan yang dikemukakan oleh Mathis dan Jackson (2006) bahwa Keselamatan dan Kesehatan Kerja (K3) adalah kegiatan yang menjamin terciptanya kondisi kerja yang aman, terhindar dari gangguan fisik dan mental melalui pembinaan dan pelatihan, pengarahan dan kontrol terhadap pelaksanaan tugas dari para karyawan dan pemberian bantuan sesuai dengan aturan yang berlaku, baik dari lembaga pemerintah maupun perusahaan dimana mereka bekerja. Keselamatan dan kesehatan kerja juga memiliki tujuan yang lebih penting yaitu mewujudkan tenaga kerja yang sehat, selamat dan produktif sehingga dapat memiliki kinerja dan prestasi yang baik.

Dari beberapa teori yang dikemukakan diatas jelaslah bahwa Keselamatan dan Kesehatan Kerja (K3) mempengaruhi kinerja karyawan, sebab kondisi kerja yang aman, nyaman dan adanya jaminan terhadap keselamatan dan kesehatan kerja karyawan akan mewujudkan karyawan yang yang sehat, selamat dan produktif sehingga dapat memiliki kinerja yang baik.

\section{Pengaruh Lingkungan Kerja terhadap Kinerja}

Pada hasil penelitian diperoleh, variabel Lingkungan kerja berpengaruh signifikan terhadap Kinerja karyawan di PT. Samudera Perdana. Hasil penelitian ini sejalan dengan hipotesis penelitian yang menyatakan bahwa Lingkungan kerja berpengaruh terhadap Kinerja karyawan di PT.Samudera Perdana. Hasil penelitian ini sesuai dengan yang dikemukakan oleh Slemania (2008) menyatakan bahwa tinggi rendahnya kinerja karyawan dipengaruhi oleh faktor kenyaman kerja yang mana hal itu juga dipengaruhi oleh faktor lingkungan kerja. Ketidaknyaman saat bekerja merupakan kondisi yang sangat tidak baik bagi tenaga kerja dalam beraktivitas, karena pekerja akan melakukan aktivitasnya yang kurang optimal dan akan menyebabkan lingkungan kerja yang tidak bersemangat dan 
membosankan, sebaliknya apabila pekerja akan melakukan aktivitas dengan optimal, dikarenakan kondisi lingkungan pekerjaan yang sangat baik dan mendukung.

Dengan demikian dapat disimpulkan bahwa Kondisi lingkungan kerja yang aman dan nyaman dapat membuat karyawan menjadi sehat dan produktif, semakin produktif karyawan akan meningkatkan kinerja dan hasil kerja yang tinggi.

\section{KESIMPULAN DAN SARAN}

Berdasarkan hasil analisis dan pembahasan yang telah diuraikan pada bab sebelumnya, maka peneliti menarik kesimpulan sebagai berikut:

1. Bahwa hasil pengujian secara parsial variabel Keselamatan dan Kesehatan Kerja (K3) berpengaruh terhadap Kinerja Karyawan PT. Samudera Perdana. Keselamatan dan kesehatan kerja memiliki tujuan yang penting yaitu mewujudkan tenaga kerja yang sehat, selamat dan produktif sehingga dapat memiliki kinerja dan prestasi yang baik.

2. Bahwa hasil pengujian secara parsial variabel Lingkungan Kerja berpengaruh terhadap Kinerja karyawan PT.Samudera Perdana. Karyawan akan melakukan aktivitas kerja dengan optimal, dikarenakan kondisi lingkungan pekerjaan yang sangat baik dan mendukung.

3. Bahwa hasil pengujian secara simultan variabel bebas Keselamatan dan Kesehatan Kerja (K3) $\left(X_{1}\right)$ dan Lingkungan Kerja $\left(X_{2}\right)$ secara serempak berpengaruh signifikan terhadap variabel terikat Kinerja (Y) karyawan pada PT.Samudera Perdana sebesar $68.4 \%$ dan sisanya sebesar $31,6 \%$ merupakan variabel lain yang tidak diteliti dalam penelitian ini.

Saran-saran yang dapat penulis berikan berdasarkan hasil dari penelitian ini adalah sebagai berikut:

1. Keselamatan dan Kesehatan Kerja (K3) perlu diperhatikan lagi, terutama kepada karyawan yang memiliki masa kerja lebih dari 5 tahun, sebab hal ini membuktikan loyalitas karyawan terhadap perusahaan, sehingga jaminan Keselamatan dan Kesehatan Kerja (K3) harus ada. . Jika jaminan Keselamatan dan Kesehatan Kerja (K3) diperhatikan, pasti akan berdamapak pada peningkatan kinerja karyawan.

2. Lingkungan Kerja di PT.Samudera Perdana juga perlu mendapatkan perhatian, sebab kondisi lingkungan kerja yang aman dan nyaman dapat membuat karyawan menjadi sehat dan produktif, semakin produktif karyawan akan meningkatkan kinerja dan hasil kerja yang tinggi.

3. Bagi peneliti selanjutnya sebaiknya memasukkan variabel lain selain dari Keselamatan dan Kesehatan Kerja ( K3 ) dan Lingkungan Kerja sebagai predictor variabel bagi Kinerja karyawan, sehingga dapat diperoleh informasi yang lebih banyak tentang faktor-faktor yang mempengaruhi Kinerja karyawan. Dan bagi perguruan tinggi bisa menjadi acuan bagi mahasiswa yang ingin melakukan penelitian yang berkaitan dengan variabel yang diteliti di penelitian ini. 


\section{REFERENSI}

Arikunto, Suharsimi. 2002. Prosedur Penelitian. Cetakan ke-13. Jakarta: Rinekacipta.

Bambang, Swasto. 2011. Manajemen Sumber Daya Manusia. Malang:UB Press.

Dessler, Gary. 2000. Manajemen Sumberdaya Manusia. Jakarta: PT. Perhalindo.

Dewi, Rijuna.2006. Pengaruh Keselamatan dan Kesehatan Kerja (K3) Terhadap Kinerja Karyawan Pada Ecogreen Oleochemicals Medan Plant. Skripsi. Fakultas Ekonomi. Universitas Sumatera Utara. Medan.

Husni, Lalu. 2005. Hukum Ketenagakerjaan Indonesia. Jakarta: PT Raja Grafindo Persada.

Konradus, Danggur. 2006. Keselamatan dan Kesehatan Kerja: Membangun SDM Pekerja Yang

Sehat, Produktif dan Kompetitif. Jakarta: Litbang Danggur \& Partners.

Mahsun, Moh. 2006. Pengukuran Kinerja Sektor Publik. Yogyakarta: BPFE.

Mangkunegara, Anwar Prabu. 2011. Manajemen Sumber Daya Manusia Perusahaan. Bandung: Rosda.

Manullang, M. 2000. Manajemen Personalia. Jakarta: Ghalia Indonesia.

Mathis, R.L. \& J.H. Jackson. 2002. Human Resource Management: Manajemen Sumber Daya Manusia. Terjemahan Dian Angelia. Jakarta: Salemba Empat.

Narbuko Choliddan Abu Achmadi. 2004. Metodologi Penelitian. Jakarta: Bumi Aksara.

Prawirosentono, Suyadi. 1999. Kebijakan Kinerja Karyawan. Yogyakarta: BPFE.

Rivai, Veltzhal. 2005. Manajemen Sumber Daya Manusia untuk Perusahaan. Jakarta: PT. Raja Grafindo Persada.

Sedarmayanti. 2011. Manajemen SumberDaya Manusia, Reformasi Birokrasi dan Manajemen Pegawai Negeri Sipil. Cetakan Kelima. Bandung:PT RefikaAditama.

Singarimbun, Masri dan Effendi, Sofyan. 2004. Metode Penelitian survey. Edisi Kedua. Yogyakarta: LP3ES.

Sugyiono. 2006. Statistika Untuk Penelitian. Bandung: Alfabeta.

Suharyadi, Purwanto. 2004. Statistika Dasar. Jakarta: PT. Raja Grafindo Persada.

Suma'mur, P.K. 1981. Keselamatan Kerja dan Pencegahan Kecelakaan. Jakarta: Gunung Agung. 1996. Higiene Perusahaan dan Kesehatan Kerja. Jakarta: Gunung Agung.

Sunyoto, Danang. 2013. Teori, Kuesioner, dan Analisis Data Sumber Daya Manusia. Yogyakarta: CAPS (Centre for Academic Publishing Services).

Swasto, Bambang. 2011. Manajemen Sumber Daya Manusia. Malang: UB Press.

Yuli, Sri Budi Cantika.2005. Manajemen Sumber Daya Manusia. Malang: UMM Press. 